\title{
biomolecules
}

ISSN 2218-273X

www.mdpi.com/journal/biomolecules/

Article

\section{Enantiocomplementary Yarrowia lipolytica \\ Oxidoreductases: Alcohol Dehydrogenase 2 and Short Chain Dehydrogenase/Reductase}

\section{Kamila Napora-Wijata ${ }^{1}$, Gernot A. Strohmeier ${ }^{1,2}$, Manoj N. Sonavane ${ }^{1}$, Manuela Avi ${ }^{3}$, Karen Robins ${ }^{3}$ and Margit Winkler ${ }^{1}$ *}

1 ACIB (Austrian Centre of Industrial Biotechnology) GmbH, Petersgasse 14/III, Graz 8010, Austria; E-Mails: kamila.napora@acib.at (K.N.-W.); gernot.strohmeier@acib.at (G.A.S.); manojsonavane4@gmail.com (M.N.S.)

2 Institute of Organic Chemistry, TU Graz, Stremayrgasse 9, Graz 8010, Austria

3 LONZA AG, Rottenstrasse 6, Visp 3930, Switzerland;

E-Mails: m.avi@gmx.net (M.A.); karen.robins@lonza.com (K.R.)

* Author to whom correspondence should be addressed; E-Mail: margit.winkler@acib.at; Tel: +43-316-873-9333; Fax: +43-316-873-9308.

Received: 3 July 2013; in revised form: 31 July 2013 / Accepted: 2 August 2013 /

Published: 12 August 2013

\begin{abstract}
Enzymes of the non-conventional yeast Yarrowia lipolytica seem to be tailor-made for the conversion of lipophilic substrates. Herein, we cloned and overexpressed the Zn-dependent alcohol dehydrogenase ADH2 from Yarrowia lipolytica in Escherichia coli. The purified enzyme was characterized in vitro. The substrate scope for $Y l \mathrm{ADH} 2$ mediated oxidation and reduction was investigated spectrophotometrically and the enzyme showed a broader substrate range than its homolog from Saccharomyces cerevisiae. A preference for secondary compared to primary alcohols in oxidation direction was observed for $Y l \mathrm{ADH} 2$. 2-Octanone was investigated in reduction mode in detail. Remarkably, $Y l A D H 2$ displays perfect $(S)$-selectivity and together with a highly $(R)$-selective short chain dehydrogenase/ reductase from Yarrowia lipolytica it is possible to access both enantiomers of 2-octanol in >99\% ee with Yarrowia lipolytica oxidoreductases.
\end{abstract}

Keywords: Zn-dependent alcohol dehydrogenase; Yarrowia lipolytica; biooxidation; short chain dehydrogenase/reductase; medium chain secondary alcohols; enantioselective reduction 


\section{Introduction}

Chiral alcohols are valuable building blocks for pharmaceuticals and agrochemicals [1] and a multitude of studies have been devoted on biocatalytic methodologies for their production. Nevertheless, there is still a high demand for new enzymes, which operate on specific substrates with high activity and selectivity. Especially, lipophilic compounds are a challenge for classical biocatalysis because substrate availability is low in the aqueous phase in which the enzymes are usually present. The non-conventional yeast Yarrowia lipolytica is typically found in lipid-rich media [2] and therefore its enzymes are thought to be evolved to metabolize non-polar substrates [3]. The work of Fantin et al. on new alcohol oxidation activities showed, for example, that Yarrowia lipolytica alcohol dehydrogenases (ADHs) are highly interesting candidates for biocatalysis [4]. In vivo, yeast ADHs are mostly responsible for ethanol formation or consumption and cofactor balance. In vitro, ADH1 from Saccharomyces cerevisiae (ScADH1; E.C: 1.1.1.1) is used for cofactor recycling with EtOH as the sacrificial substrate in order to promote NADH dependent enzyme catalyzed reduction [5]. ScADH1 is a well-studied Zn- and NAD(H) dependent enzyme [6] with known crystal structure (pdb code: 2hcy). The Yarrowia lipolytica genome codes for five homologous Zn-dependent ADHs. They are currently filed as putative enzymes [7]. Three of these five proteins were annotated as putative ADH1, ADH2, and $\mathrm{ADH} 3$, one as a protein with similarity to putative Yarrowia lipolytica ADH3, and one as protein with similarity to mitochondrial ADH3 of $S$. cerevisiae. Of these proteins, ADH2 showed the highest similarity to $S c \mathrm{ADH} 1$ and was therefore chosen as a target enzyme (Table 1). $\mathrm{YlADH} 2$ shows sequence similarity to alcohol dehydrogenases from other yeasts [8], e.g., Pichia stipitis ADH1 (74\% identity) [9], Candida maltosa ADH2A [10] (73\% identity), S. cerevisiae ADH3 (71\% identity), and Hansenula polymorpha ADH (75\% identity) [11]. Whereas ScADH3-like enzymes from different yeasts are mitochondrial enzymes [3,12], the primary sequences of ScADH1 and YlADH2have no mitochondrial targeting sequence according to the PSORTII algorithm [13]. Herein we report the heterologous expression of Yarrowia lipolytica $\mathrm{ADH} 2$, the enzyme's substrate scope and its enantioselectivity. Further, $\mathrm{YlADH} 2$ is compared to a Yarrowia lipolytica short chain dehydrogenase/ reductase (YlSDR), which is enantiocomplementary and offers the possibility to synthesize the other enantiomer of 2-octanol.

Table 1. Protein similarities of Saccharomyces cerevisiae ADH1 and Yarrowia lipolytica

Zn-dependent ADHs. italics: Identities (\%), bold: positives (\%).

\begin{tabular}{ccccccc}
\hline & ScADH1 & YlADH1 & YlADH2 & YlADH3 & YlADH & YlADH \\
\hline Acc. Nr.: & NP_014555 & XP_503282 & XP_504077 & XP_500127 & XP_500087 & XP_503672 \\
NP_014555 & 100 & 68 & 68 & 69 & 66 & 54 \\
XP_503282 & $\mathbf{8 0}$ & 100 & 94 & 98 & 81 & 57 \\
XP_504077 & $\mathbf{8 2}$ & $\mathbf{9 8}$ & 100 & 94 & 79 & 56 \\
XP_500127 & $\mathbf{8 0}$ & $\mathbf{9 9}$ & $\mathbf{9 7}$ & 100 & 82 & 58 \\
XP_500087 & $\mathbf{8 0}$ & $\mathbf{9 0}$ & $\mathbf{8 5}$ & $\mathbf{9 0}$ & 100 & 53 \\
XP_503672 & $\mathbf{7 0}$ & $\mathbf{7 0}$ & $\mathbf{7 0}$ & $\mathbf{7 1}$ & $\mathbf{6 9}$ & 100 \\
\hline
\end{tabular}




\section{Results and Discussion}

In continuation of our search for versatile oxidoreductases especially for lipophilic compounds [14], we amplified the ADH2 gene from genomic DNA of the Yarrowia lipolytica CLIB122 strain and cloned it into two different vector systems. In addition to the native ADH2 sequence, an $\mathrm{N}$-terminal His-tag was introduced to facilitate enzyme purification. $Y l \mathrm{ADH} 2$ expression in the pEHisTEV vector [15] - that adds an $N$-terminal His-tag and a TEV protease cleavage site to the protein of interest - with the T7 promoter resulted in approximately identical expression level compared to untagged YlADH2 expressed from pMS470, a vector with tac promoter [16] (see Figures S1 and S2 in the supplementary information). His-tagged $Y l A D H 2$ was then purified by Ni-affinity chromatography and used for in vitro characterization. Investigation of the cofactor specificity revealed, as expected, a strong preference of $Y l \mathrm{ADH} 2$ for $\mathrm{NAD}(\mathrm{H})$ over $\mathrm{NADP}(\mathrm{H})$ [6]. We were particularly interested in the substrate tolerance of $Y l \mathrm{ADH} 2$ and investigated the oxidation of the following substrates: EtOH, 2-propanol, 1-butanol, (2R,3R)-butanediol, cyclohexanol, 4-methyl-2-pentanol, rac-2-heptanol, 1-octanol, rac-2-octanol, $(R)$-2-octanol, $(S)$-2-octanol, 1-nonanol, rac-2-nonanol, 1-decanol, 1-dodecanol, 1-phenylethanol, $(R)$-2-amino-2-phenylethanol, $(S)$-2-amino-2-phenylethanol, phenylacetaldehyde, adonitol, arabitol, xylitol, sorbitol, and mannitol. Due to the lipophilicity of long chain alcohols, surfactants were used to increase their solubility under assay conditions [17].

Table 2. Exploration of the substrate spectrum of $Y l \mathrm{ADH} 2$.

\begin{tabular}{|c|c|c|c|c|}
\hline Entry & Substrate & $\begin{array}{c}\text { Relative oxidation } \\
\text { activity (\%) }\end{array}$ & Substrate & $\begin{array}{c}\text { Relative reduction } \\
\text { activity (\%) }\end{array}$ \\
\hline 1 & 2-propanol & 53 & acetone & $<5$ \\
\hline 2 & 1-butanol ${ }^{\text {a }}$ & 9 & & \\
\hline 3 & rac-4-methyl-2-pentanol & 6 & & \\
\hline 4 & rac-2-heptanol ${ }^{\text {a }}$ & 64 & & \\
\hline 5 & 1-octanol ${ }^{\mathrm{b}}$ & 7 & & \\
\hline 6 & rac-2-octanol ${ }^{\text {a }}$ & $100^{\mathrm{c}}$ & 2-octanone & $100^{\mathrm{d}}$ \\
\hline 7 & 1-nonanol ${ }^{\mathrm{b}}$ & 7 & & \\
\hline 8 & rac-2-nonanol ${ }^{\text {a }}$ & 81 & 2-nonanone & 106 \\
\hline 9 & 1-decanol ${ }^{\mathrm{b}}$ & 6 & & \\
\hline 10 & rac-2-decanol ${ }^{\mathrm{a}}$ & 77 & 2-decanone & 100 \\
\hline
\end{tabular}

Ethanol is by far the best substrate for ADH1 from Saccharomyces cerevisiae [6] and YlADH2 can also oxidize EtOH, however, its specific activity is two orders of magnitude lower than that of a commercial preparation of $\mathrm{ScADH} 1$ (>300 U/mg as specified by the manufacturer). In this study, the above-mentioned compounds were subjected to both $Y l \mathrm{ADH} 2$ and $S c \mathrm{ADH} 1$ oxidation. Except for $\mathrm{EtOH}$ (see above) and 2-propanol (197 $\pm 77 \mathrm{mU} / \mathrm{mg}), S c \mathrm{ADH} 1$ showed no significant activity for any substrate. $Y l \mathrm{ADH} 2$ exhibited a much broader substrate tolerance than its homolog from Saccharomyces cerevisiae (Table 2). Substrates which showed less than 5\% of the activity towards 2-octanol oxidation are not listed in Table 2 . The highest specific activity was observed for the oxidation of 
racemic 2-octanol $\left(1.1 \pm 0.1 \mathrm{U} \cdot \mathrm{mg}^{-1}\right)$, which is a value similar to that observed for Yarrowia lipolytica short chain dehydrogenase/reductase YlSDR (NCBI Accession Nr. XP_500963.1) [14]. Both enzymes clearly preferred secondary to primary alcohols. However, in contrast to $Y l$ SDR, YlADH2 was not able to oxidize carbohydrate substrates.

The optimal reaction temperature for the oxidation of racemic-2-octanol was determined between $25{ }^{\circ} \mathrm{C}$ and $37{ }^{\circ} \mathrm{C}$. $\mathrm{YlADH} 2$ showed a plateau of highest activity between $28{ }^{\circ} \mathrm{C}$ and $33{ }^{\circ} \mathrm{C}$. The optimal $\mathrm{pH}$ of the reaction is strongly dependent on the reaction buffer as depicted in Figure 1 1. Whereas high activities were observed at $\mathrm{pH} 9.5$ in carbonate and glycine buffer, the same $\mathrm{pH}$ was detrimental in borate buffer. A similarly negative effect of borate buffer was also observed for the YlSDR enzyme.

Figure 1. $\mathrm{pH}$ optimum of $Y \mathrm{ADDH} 2$ catalyzed oxidation of $(S)$-2-octanol. • : citrate; a: potassium phosphate; $\boldsymbol{\Delta}$ : Tris- $\mathrm{HCl}$; —: borate; $\mathrm{X}$ : glycine; $\bullet$ : carbonate.

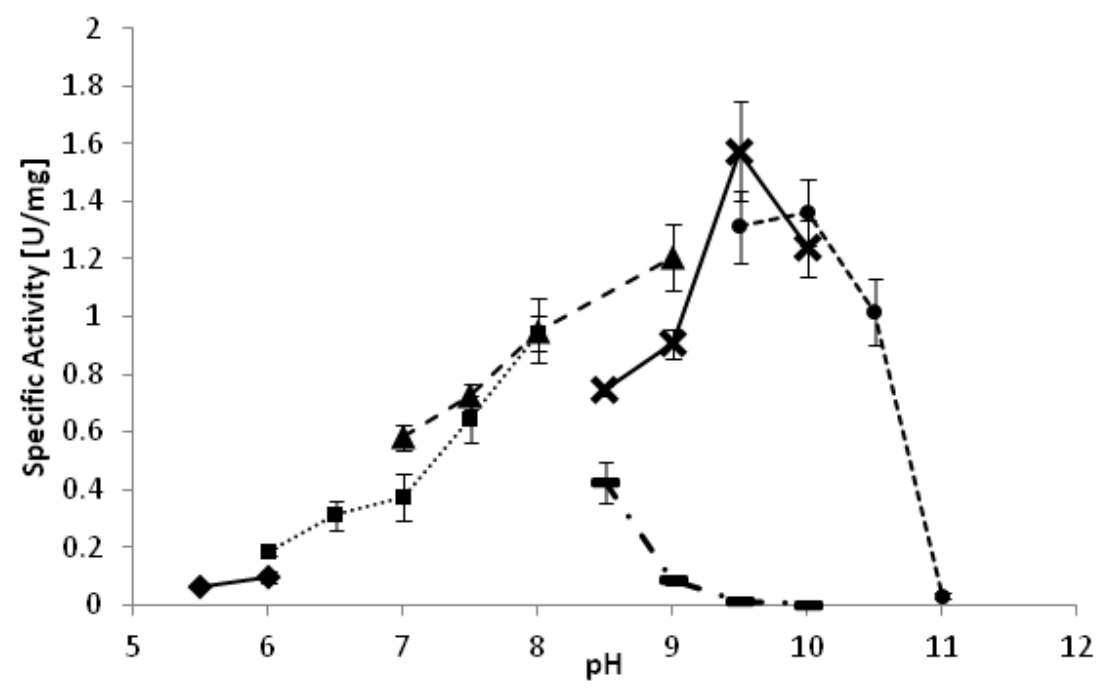

Figure 2. $\mathrm{pH}$ optimum of $\mathrm{YlADH} 2$ catalyzed reduction of 2-octanone. •: citrate; a: potassium phosphate; $\boldsymbol{\Delta}$ : Tris-HCl.

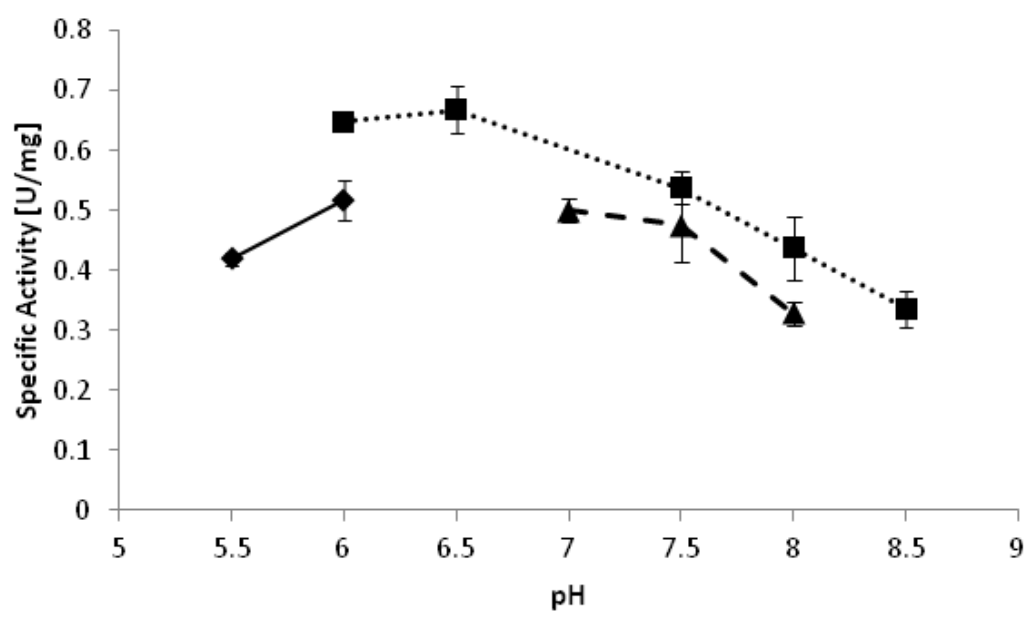

YlSDR was catalyzing the reduction of several substrates and displayed its highest activity for ribulose [14]. YlADH2, by contrast, was highly specific for medium chain lipophilic ketone substrates among those tested (see experimental section). Relative specific activities for substrate reduction are 
shown in Table 2 and the absolute values were approximately $0.5 \mathrm{U} \cdot \mathrm{mg}^{-1}$. The optimal $\mathrm{pH}$ of the reduction of 2-octanone appeared to be $\mathrm{pH} 6.5$ (Figure 2). Interestingly, reduction reactions often proceed better at relatively low $\mathrm{pH}$ as compared to oxidations $[18,19]$. In the mechanism of a reduction reaction, a hydride is transferred from the nicotinamide donor to the substrate simultaneously to the addition of a proton. At a low $\mathrm{pH}$, the amino acid residues of the protein are predominantly protonated, which facilitates the proton transfer. In oxidation direction, a proton needs to be removed from the substrate, typically from a basic amino acid residue in the active site. In this case, the deprotonated state of the protein at elevated $\mathrm{pH}$ seems to be beneficial.

The determination of kinetic parameters for $Y l \mathrm{ADH} 2$ mediated oxidation and reduction showed that the $k_{\text {cat }}$ value for reduction of 2-octanone is approximately half of the value of the respective oxidation (Table 3).

Table 3. Apparent kinetic parameters for $Y l A D H 2$.

\begin{tabular}{cccc}
\hline & \multicolumn{2}{c}{ Oxidation } & Reduction \\
\hline & $(S)$-2-octanol & $\mathrm{NAD}^{+}$ & 2-octanone \\
$K_{\mathrm{m}}[\mathrm{mM}]$ & $1.42 \pm 0.03$ & $17.8 \pm 1.26$ & $5.38 \pm 0.76$ \\
$k_{\mathrm{cat}}\left[\mathrm{s}^{-1}\right]$ & $1.05 \pm 0.52$ & $3.43 \pm 0.05$ & $0.56 \pm 0.04$ \\
$k_{\mathrm{cat}} / K_{\mathrm{m}}$ & $0.74 \pm 0.50$ & $0.19 \pm 0.07$ & $0.10 \pm 0.16$ \\
{$\left[\mathrm{~s}^{-1} \cdot \mathrm{mM}^{-1}\right]$} & & & \\
\hline
\end{tabular}

Alcohol dehydrogenases are often used as catalysts for enantioselective syntheses - on laboratory scale and in industrial processes [20,21]. To determine the enantiopreference of $Y l \mathrm{ADH} 2$, the single enantiomers of 2-octanol were subjected to $\mathrm{NAD}^{+}$mediated oxidation. The monitored NADH formation was significantly faster in case of $(S)$-2-octanol $\left(1.1 \mathrm{U} \cdot \mathrm{mg}^{-1}\right)$ compared to the $(R)$-enantiomer $\left(<0.2 \mathrm{U} \cdot \mathrm{mg}^{-1}\right)$ - a first indication for $(S)$-selectivity of the enzyme. In order to verify this result, we investigated the reaction in reduction direction. Therefore, 2-octanone was used as the substrate and the products were analyzed by chiral gas chromatography after derivatization to the corresponding acetates. $Y l$ ADH2 produced exclusively the $(S)$-enantiomer (>99\% ee). By contrast, the $(R)$-enantiomer was obtained in $>99 \%$ ee in case that $Y l$ SDR was applied as the biocatalyst (Figure 3)

Figure 3. Time dependent formation of $\bullet(S)$-2-octanol (<99\% ee) catalyzed by YlADH2 and $(R)$-2-octanol $(<99 \%$ ee $)$ catalyzed by $Y l$ SDR.

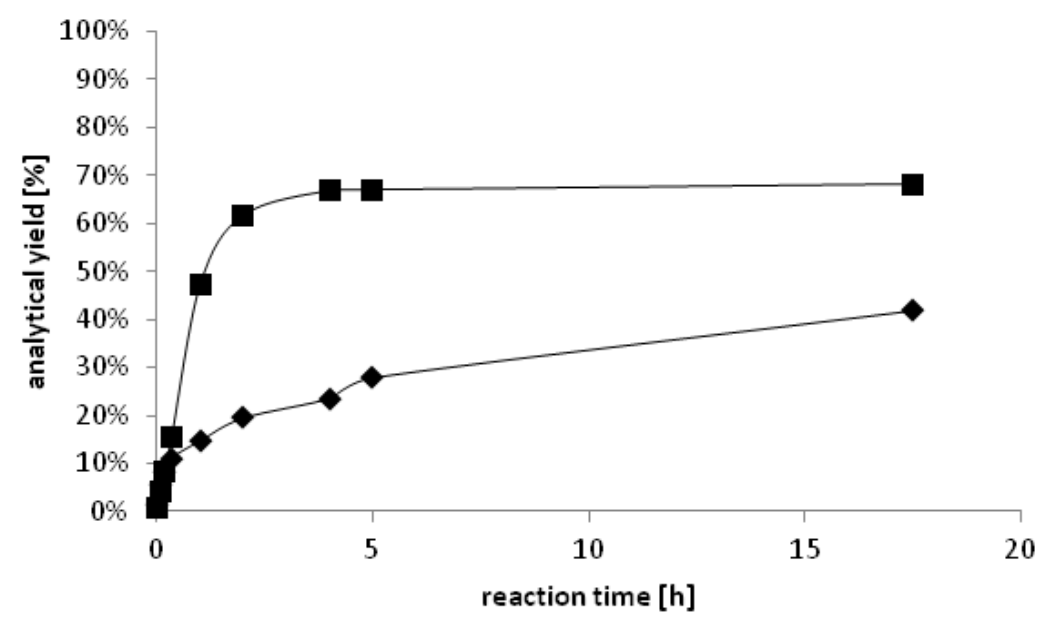


In order to improve the conversions, we applied cofactor recycling, using glucose dehydrogenase (GDH) and formate dehydrogenase (FDH) [22] in different combinations of enzyme and co-substrate concentrations. The cofactor recycling system GDH/glucose gave moderate conversions in comparison to FDH/formate. Using $0.02 \mathrm{U}$ of FDH in combination with sodium formate $(100 \mathrm{mM})$ at $0.5 \mathrm{~mL}$ scale, $70 \%$ of 2-octanone were reduced to $(S)$-2-octanol in $>99 \%$ ee within one hour. After $2.5 \mathrm{~h}$, the conversion was $83 \%$ and full conversion $(>99 \% e e$ ) was observed after a reaction time of $<16 \mathrm{~h}$. Enantiomerically pure lipophilic alcohols can be used as derivatizing agent for the enantioseparation of carboxylic acids [23] or e.g., for the preparation of functional materials. (S)-2-Octanol, for instance, was used as the chiral selector in microemulsion electrokinetic chromatography [24]. The $(R)$-enantiomer served as a precursor for chiral liquid crystals [25]. The two Yarrowia lipolytica oxidoreductases described herein offer the possibility to produce both enantiomers of 2-octanol in highly pure form, possibly by oxidative kinetic resolution of racemic 2-octanol, or by the reduction of prochiral 2-octanone (Scheme 1).).

Scheme 1. Routes to enantiomerically pure $(S)$ - and (R)-2-octanol via Yarrowia lipolytica oxidoreductases.

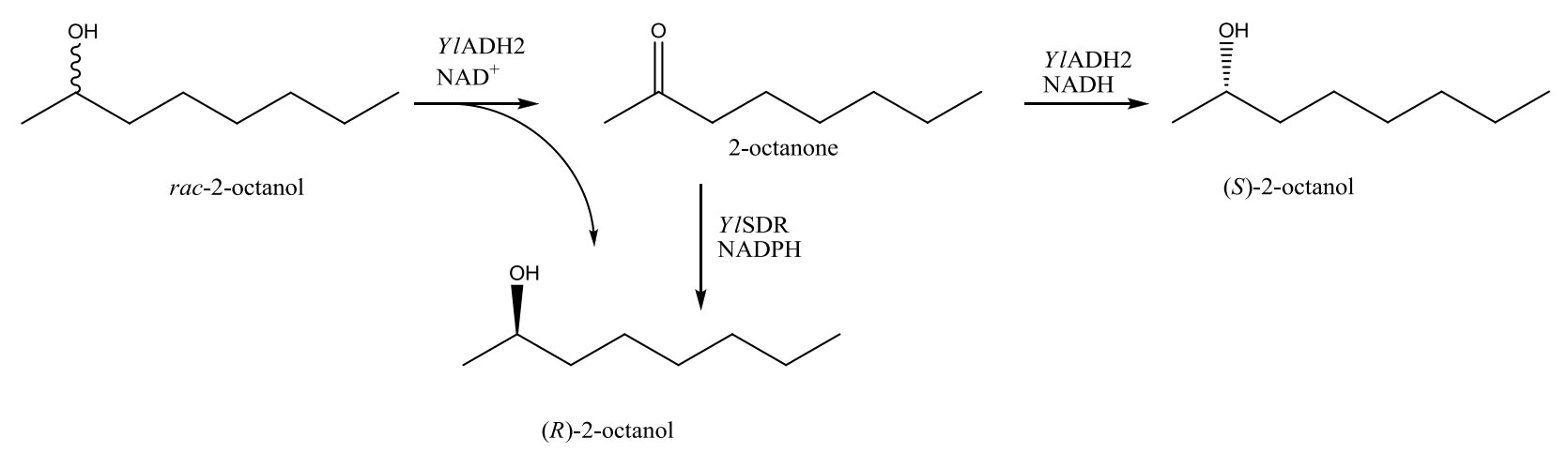

\section{Experimental}

\subsection{General}

Yarrowia lipolytica CLIB 122 (supplementary information Figure S3) was obtained from Centre International de Ressources Microbiennes (CIRM, France). E. coli cells were cultivated in RS 306 and Multitron shakers (Infors AG), and the cells were harvested with Avanti centrifuge J-20 (Beckman Coulter). Cell pellets were disrupted with a Branson 102C converter, power was supplied with a Branson Sonifier 250 or a French Press model and cell free extract was obtained by centrifugation in Ultracentrifuge Optima LE80K (Beckman Coulter). Enzymes were purified using a HisTrap ${ }^{\text {TM }}$ FF 5 mL column on an ÄKTA Purifier 100 with Frac-950, software Unicorn 4.11, and desalted using a HiPrep $^{\text {TM }}$ 26/10 Desalting column on an ÄKTA Prime, software PrimeView 5.0 (GE Healthcare Life Sciences). Protein samples were analyzed with $4-12 \%$ NuPAGE $^{\circledR}$ Bis-Tris Gel (Invitrogen) and photometric measurements were carried out on Synergy Mx plate reader (BioTek) using the Gen5.11 Software. Chiral GC analyses were carried out on a Hewlett-Packard 6890 instrument. NADH and $\mathrm{NAD}^{+}$(sodium salt; 97\% pure) was obtained from Roche Diagnostics. GDH was obtained from DSM Innovative Synthesis BV. 2-Nonanone and 2-decanone were purchased from Alfa Aesar and all other 
chemicals including alcohol dehydrogenase from Saccharomyces cerevisiae (lyophilized powder, $\geq 300$ $\mathrm{U} \cdot \mathrm{mg}^{-1}$, order number A7011) were purchased from Sigma-Aldrich/Fluka and used as received.

\subsection{Isolation of Genomic DNA and Gene Cloning}

Genomic DNA from Yarrowia lipolytica strain CLIB 122 was isolated according to the published procedure [26].

The fragment corresponding to $Y l$ ADH2 was amplified from genomic DNA using Phusion ${ }^{\circledR}$ HighFidelity DNA polymerase (Finnzymes) with the following primers: pEHisTEVmutY1ADH2_f: 5'-TAC

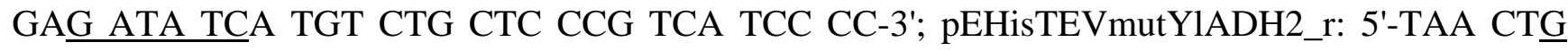
CGG CCG CTT ACT TGG AGG TGT-3'. The EcoRV and NotI restriction sites are underlined. The gene was cloned into the pEHisTEV vector, previously digested with EcoRV and NotI.

$N$-Terminally tagged and untagged $Y l A D H 2$ were cloned into vector pMS470 as follows: the fragments were amplified from pEHisTEV:ADH2 using Phusion ${ }^{\circledR}$ High-Fidelity DNA polymerase (Finnzymes) and following primers: pMS470d8ADH2_f 5'-TAT CAC ATA TGT CTG CTC CCG TCA TC-3'; pMS470d8ADH2_r 5'-TTT CTG CAT GCT TAC TTG GAG GTG TC-3'; pMS470d8_HIS-TEVADH2_f 5'-ATA CAT ATG TCG TAC TAC CAT CAC CAT CAC C-3' and pMS470d8_HIS-TEVADH2_r 5'-ATA GCA TGC TTA CTT GGA GGT GTC CAG-3'; The restriction sites $N d e \mathrm{I}$ and $S p h \mathrm{I}$ are underlined. Amplification conditions were: $98{ }^{\circ} \mathrm{C}$ for $5 \mathrm{~min}$, followed by 30 cycles of $98{ }^{\circ} \mathrm{C}$ for $30 \mathrm{~s}, 55^{\circ} \mathrm{C}$ for $30 \mathrm{~s}$, and $72{ }^{\circ} \mathrm{C}$ for $30 \mathrm{~s}$, then a final incubation of $72{ }^{\circ} \mathrm{C}$ for 7 min. The PCR products were gel separated and the excised DNA was purified with the QIAquick Gel Extraction Kit. The DNA was digested with NdeI and SphI restriction enzymes (Fermentas) in the presence of Tango buffer (Fermentas) and column purified according to QIAquick PCR purification protocol. The genes were cloned into the pMS470 vector, previously digested with NdeI and SphI and dephosphorylated with Calf Intestine Alkaline Phosphatase (Fermentas) in the presence of FastDigest buffer (Fermentas), using T4 polymerase (Fermentas) in T4 DNA ligase buffer (Fermentas), at room temperature for $1 \mathrm{~h}$.

The fragment corresponding to YlSDR was amplified using Phusion ${ }^{\circledR}$ High-Fidelity DNA polymerase (Finnzymes) with the following primers: YaliSDR2470_f: 5'-AAT CAC ATA TGC CTG CAC CAG CAA CCT AC-3' and YaliSDR2470_r: 5'-AAT CAG CAT GCT CAA GGA CAA CAG TAG CC-3'. The NdeI and SphI restriction sites are underlined. Amplification conditions were: $98{ }^{\circ} \mathrm{C}$ for $30 \mathrm{~s}$, followed by 30 cycles of $98{ }^{\circ} \mathrm{C}$ for $10 \mathrm{~s}, 58{ }^{\circ} \mathrm{C}$ for $20 \mathrm{~s}$, and $72{ }^{\circ} \mathrm{C}$ for $30 \mathrm{~s}$, then a final incubation of $72{ }^{\circ} \mathrm{C}$ for $7 \mathrm{~min}$. The PCR products were gel separated and the excised DNA was purified with the QIAquick Gel Extraction Kit (QIAGEN). The DNA was digested with NdeI and SphI restriction enzymes (Fermentas) in the presence of Tango buffer (Fermentas) and column purified according to the QIAquick PCR purification protocol. The gene was cloned into the pK470 vector, which contained an $N$-terminal His-Tag (for the vector map, see Figure S4 supplementary information). The pK470 vector was digested with $N d e \mathrm{I}$ and $S p h \mathrm{I}$ and gel purified according the procedure described above, prior to the ligation. Ligation was carried out with $\mathrm{T} 4$ polymerase (Fermentas) in T4 DNA ligase buffer (Fermentas), at room temperature for $1 \mathrm{~h}$.

The constructs were transformed into electrocompetent E. coli TOP10 F' cells (Invitrogen) and cells were plated out on LB with $50 \mu \mathrm{g} / \mathrm{mL}$ kanamycin (for pEHisTEV and pK470) or $100 \mu \mathrm{g} / \mathrm{mL}$ ampicillin 
(for pMS470). The plasmids were isolated with the GeneJET ${ }^{\text {тM }}$ Plasmid Miniprep Kit (Fermentas) and the sequences confirmed by LGC genomics. The plasmids were then transformed into electrocompetent E. coli BL21 (DE3) Gold cells (Stratagen).

\subsection{Expression and Purification}

Expression and purification of $Y l S D R$ was carried out as described previously (supplementary information Figure S5) [14]. E. coli BL21 (DE3) Gold harboring ADH2 plasmids were cultivated as follows: overnight cultures $[50 \mathrm{~mL} \mathrm{LB}$ with $50 \mu \mathrm{g} / \mathrm{mL}$ kanamycin (for pEHisTEV) or $100 \mu \mathrm{g} / \mathrm{mL}$ ampicillin (for pMS470)] were inoculated with a single colony and grown overnight at $37{ }^{\circ} \mathrm{C}$ in an orbital shaker at $110 \mathrm{rpm} .500 \mathrm{~mL} \mathrm{LB}$ medium with the appropriate antibiotic in 2-L baffled Erlenmeyer flasks were inoculated to an OD of 0.1 . These main cultures were grown at $37{ }^{\circ} \mathrm{C}$ and $110 \mathrm{rpm}$ to an OD of $0.4-0.6$, cooled on ice for $30 \mathrm{~min}$, induced with $0.5 \mathrm{mM}$ of IPTG and supplemented with $0.25 \mathrm{mM} \mathrm{ZnSO}_{4}$ [27]. The cultures were incubated for $20 \mathrm{~h}$ at $16{ }^{\circ} \mathrm{C}$ and $23 \times g$. The cells were harvested by centrifugation $\left(2,831 \times g, 4{ }^{\circ} \mathrm{C}, 10 \mathrm{~min}\right)$, washed with buffer, and disrupted by sonication or French press treatment in Tris/ $\mathrm{HCl}$ buffer (40 mM;0.3 M NaCl, $\mathrm{pH} 8.5$ ). After centrifugation at $72,647 \times g, 4{ }^{\circ} \mathrm{C}$ for $1 \mathrm{~h}$, the cell free extract was either stored at $-20{ }^{\circ} \mathrm{C}$ or subjected to Ni-affinity chromatography, re-buffered into potassium phosphate buffer $(50 \mathrm{mM}, 500 \mathrm{mM}$ $\mathrm{NaCl}, 40 \mathrm{mM} \mathrm{KCl} \mathrm{pH} \mathrm{8.5),} \mathrm{concentrated} \mathrm{with} \mathrm{Vivaspin} 20$ (Sartorius Stedim Biotech S.A), shock frozen in liquid nitrogen, and stored at $-80{ }^{\circ} \mathrm{C}$. Protein concentrations were determined using the Bradford method.

\subsection{Substrate Scope}

Alcohol dehydrogenase activity of recombinant $Y l A D H 2$ and commercial ScADH1 were determined by following the reduction of $\mathrm{NAD}(\mathrm{P})^{+}$at $340 \mathrm{~nm}$ in UV-Star Polystyrene plates (Greiner Bio-One). Specifically, $20 \mu \mathrm{L}$ substrate solution (various alcohols and sugars, $100 \mathrm{mM}$ in $50 \mathrm{mM}$ potassium phosphate, $40 \mathrm{mM} \mathrm{KCl}, \mathrm{pH} 8.5)$ was added to $140 \mu \mathrm{L}$ potassium phosphate $(50 \mathrm{mM}$, $40 \mathrm{mM} \mathrm{KCl}, \mathrm{pH} 8.5)$, followed by $20 \mu \mathrm{L}$ enzyme solution $(0.05-0.1 \mathrm{mg} / \mathrm{mL}$; ScADH1 dissolved freshly in $10 \mathrm{mM}$ sodium phosphate, $\mathrm{pH} 7.5$; purified $Y l \mathrm{ADH} 2$ was thawed on ice and diluted appropriately). The reaction was started by addition of $20 \mu \mathrm{L} \mathrm{NAD}^{+}$(or NADP $; 10 \mathrm{mM}$ in water) and monitored at $28{ }^{\circ} \mathrm{C}$ for $Y l \mathrm{ADH} 2$ and $30{ }^{\circ} \mathrm{C}$ for $S c \mathrm{ADH} 1$ for $10 \mathrm{~min}$. The following substrates were investigated: EtOH, 2-propanol, 1-butanol, (2R,3R)-butanediol, cyclohexanol, 4-methyl-2-pentanol, rac-2-heptanol, 1-octanol, rac-2-octanol, $(R)$-2-octanol, $(S)$-2-octanol, 1-nonanol, rac-2-nonanol, 1-decanol, 1-dodecanol, 1-phenylethanol, $(R)$-2-amino-2-phenylethanol, $(S)$-2-amino-2-phenylethanol, phenylacetaldehyde, adonitol, arabitol, xylitol, sorbitol, and mannitol. To substrates with limited water solubility, $4.5 \%$ or $7.5 \% \mathrm{v} / \mathrm{v}$ of Tween 20 was added to the $100 \mathrm{mM}$ substrate stock. In case of phenylacetaldehyde, the addition of $50 \%$ DMSO was necessary to ensure a homogenous reaction mixture. Each reaction was performed at least in two sets of quadruple measurements. Blanks without substrate were subtracted. Activity units are defined as the amount of enzyme producing $1 \mu$ mol of NADH per min. Specific activity was expressed as units per mg of protein.

The reduction of acetone, cyclohexanone, octanal, 2-octanone, 2-nonanone, 2-decanone, 2-dodecanone, acetophenone, phenylacetaldehyde, ribose, arabinose, xylose, glucose, mannose, lactose, and fructose 
was monitored at $340 \mathrm{~nm}$ via the oxidation of NADH in UV-Star Polystyrene plates (Greiner Bio-One). The conditions above were used with the following modifications: $4.5 \% \mathrm{v} / \mathrm{v}$ of Tween 20 was added to the $100 \mathrm{mM}$ substrate stock solution of 2-ketones and $10 \%$ Triton to octanal. The reaction was carried out at $\mathrm{pH} 7.0$ and $28{ }^{\circ} \mathrm{C}$ and it was started by addition of $20 \mu \mathrm{L}$ NADH $(7.5 \mathrm{mM}$ in water). Activity units are defined as the amount of enzyme consuming $1 \mu$ mol of NADH per min.

\subsection{Determination of pH Optima}

Optimal oxidation $\mathrm{pH}$ was determined by following the reduction of $\mathrm{NAD}^{+}$as described in section "substrate scope". (S)-2-Octanol was used as the substrate. For the different $\mathrm{pH}$ points, the following buffers were used, each in $50 \mathrm{mM}$ concentration containing $40 \mathrm{mM} \mathrm{KCl}$ : citrate $(\mathrm{pH} 5.5-6.0)$, potassium phosphate buffer $(\mathrm{pH}$ 6.0-8.0), TrisHCl $(\mathrm{pH} 7.0-9.0)$, borate $(\mathrm{pH}$ 8.5-10.0), glycine ( $\mathrm{pH}$ 8.5-10.0), and carbonate buffer ( $\mathrm{pH}$ 9.5-11.0). Similarly, the optimal $\mathrm{pH}$ for reduction was determined using 2-octanone as the substrate with above mentioned buffers.

\subsection{Determination of Kinetic Parameters}

The kinetic parameters for $(S)$-2-octanol oxidation and 2-octanone reduction as well as $\mathrm{NAD}^{+}$ reduction were determined. $(S)$-2-octanol was used in concentrations from $0.5 \mathrm{mM}$ to $15 \mathrm{mM}$ and assayed in potassium phosphate buffer $(50 \mathrm{mM}, 40 \mathrm{mM} \mathrm{KCl}, \mathrm{pH} 8.5)$. 2-Octanone was used in concentrations from $1 \mathrm{mM}$ to $40 \mathrm{mM}$ and assayed in potassium phosphate buffer $(50 \mathrm{mM}$, $40 \mathrm{mM} \mathrm{KCl}, \mathrm{pH}$ 7.0). The stock solutions contained $4.5 \%$ Tween 20 or less. Kinetic parameters for $\mathrm{NAD}^{+}$were determined by oxidation of $(S)$-2-octanol $(10 \mathrm{mM})$ in potassium phosphate buffer $(50 \mathrm{mM}$, $40 \mathrm{mM} \mathrm{KCl}, \mathrm{pH} 8.5$ ) with concentrations of $\mathrm{NAD}^{+}$from $200 \mu \mathrm{M}$ to $50 \mathrm{mM}$. All assays were performed as described in section "substrate scope" at $28{ }^{\circ} \mathrm{C}$. The results were evaluated based on Michaelis - Menten kinetics, using SigmaPlot ${ }^{\mathrm{TM}}$ version 11.0 for non-linear fitting.

\subsection{Determination of Enantioselectivity}

(S)-2-octanol was prepared under the following conditions: purified YlADH2 in potassium phosphate buffer $(50 \mathrm{mM}$, containing $40 \mathrm{mM} \mathrm{KCl}, \mathrm{pH} 6.5)$ was mixed with 2-octanone (100 $\mathrm{mM}$ in the same buffer with $7.5 \% \mathrm{v} / \mathrm{v}$ Tween 20) and NADH (100 mM in water) to give $0.16 \mathrm{mg} / \mathrm{mL}, 10 \mathrm{mM}$ and $11 \mathrm{mM}$ end concentration, respectively, in total volumes of $500 \mu \mathrm{L}$. The reaction proceeded at $28{ }^{\circ} \mathrm{C}$ in an Eppendorf Thermomixer at $600 \mathrm{rpm}$. For each time-point, an extra sample was sacrificed. Substrate and products were extracted into $500 \mu \mathrm{L}$ of ethyl acetate. A triethylamine-4(dimethylamino)-pyridine stock solution [TEA-DMAP stock solution: DMAP (8.9 mg, $73.2 \mu$ mol) dissolved in TEA $(2.00 \mathrm{~mL}, 14.3 \mathrm{mmL})]$ was added to the sodium sulfate-dried ethyl acetate extract of the reaction $(500 \mu \mathrm{L}$, contains $\leq 10.0 \mathrm{mM}$ of 2-octanol) (TEA: $68.3 \mu \mathrm{L}, 490 \mu \mathrm{mol}, 98$ equivalents.; DMAP: $0.31 \mathrm{mg}, 2.5 \mu \mathrm{mol}, 0.5$ equivalents) and acetic anhydride $(23.6 \mu \mathrm{L}, 250 \mu \mathrm{mol}, 50$ equivalents). After keeping the mixture at $40{ }^{\circ} \mathrm{C}$ for $3 \mathrm{~h}$, the reaction was quenched by adding saturated sodium chloride solution $(300 \mu \mathrm{L})$ and subsequent vigorous shaking. Finally, the ethyl acetate layer was directly subjected to GC analysis on a Chirasil-Dex CB column $(25 \mathrm{~m} \times 0.32 \mathrm{~mm} ; 0.25 \mu \mathrm{m}$ film; Varian). The GC settings were as follows: injector $220{ }^{\circ} \mathrm{C} ; 1.0$ bar constant pressure $\mathrm{H}_{2}$ flow; 
temperature program: initial temperature $60{ }^{\circ} \mathrm{C}, 85^{\circ} \mathrm{C} /$ rate $1.5{ }^{\circ} \mathrm{C}$ per min, hold $3 \mathrm{~min}$; The absolute configuration of 2-octanol was assigned by comparison of the elution order on chiral GC with literature known data [28] and by derivatization of commercial $(R)$ - and $(S)$-2-octanol. Retention times were $8.0 \mathrm{~min}$ for 2-octanone, $13.9 \mathrm{~min}$ for $(S)$-octan-2-yl acetate and $17.2 \mathrm{~min}$ for $(R)$-octan-2-yl acetate.

For cofactor recycling, the same conditions as describe above were used, with the exception that also $0.03 \mathrm{U}$ of FDH and $100 \mathrm{mM}$ of sodium formate were added to the reaction and the content of NADH cofactor was reduced to $1 \mathrm{mM}$.

(R)-2-octanol was prepared under the following conditions: purified YlSDR in citrate buffer (50 mM, pH 5.0) was mixed with 2-octanone (100 mM in the same buffer with $3 \% \mathrm{v} / \mathrm{v}$ Tween 20 ) and NADPH (100 mM in water) to give $0.11 \mathrm{mg} / \mathrm{mL}, 10 \mathrm{mM}$ and $11 \mathrm{mM}$ end concentration, respectively, in total volumes of $500 \mu \mathrm{L}$. The reaction proceeded at $28{ }^{\circ} \mathrm{C}$ in an Eppendorf Thermomixer at $600 \mathrm{rpm}$. Workup and analysis were carried out as described for $(S)$-2-octanol.

\section{Conclusions}

In conclusion, we have shown that Yarrowia lipolytica harbors versatile oxidoreductases that catalyze selective oxidation and reduction reactions. From the two enzymes described herein, secondary alcohols are the preferred substrates in the oxidation direction compared to primary alcohols and aldehydes. Medium chain length ketones with the carbonyl function at position C-2 are reduced to the corresponding secondary alcohols in enantio-complementary form: whereas $Y l A D H 2$ produced the $(S)$-enantiomer in $>99 \% e e$, the $(R)$-enantiomer was obtained with $Y l$ SDR.

\section{Acknowledgements}

We are grateful to Regina Kratzer for providing the FDH expressing strain as published in [22]. Sarah S. Schindlbacher, Natalia Pankiewicz, Dorota K. Pomorska, Gerlinde Offenmüller and Thorsten Bachler are kindly acknowledged for technical support. This work has been supported by the Austrian BMWFJ, BMVIT, SFG, Standortagentur Tirol, and ZIT through the Austrian FFG-COMETFunding Program.

\section{Conflict of Interest}

The authors declare no conflict of interest.

\section{References}

1. DeWildeman, S.M.A.; Sonke, T.; Schoemaker, H.E.; May, O. Biocatalytic reductions: From lab curiosity to first choice. Acc. Chem. Res. 2007, 40, 1260-1266.

2. Barth, G.; Gaillardin, C. Yarrowia lipolytica. In Nonconventional Yeasts in Biotechnology; Wolf, K., Ed.; Springer-Verlag, Berlin Heidelberg: New York, NY, USA, 1996; pp. 313-388.

3. Fickers, P.; Benetti, P.-H.; Waché, Y.; Marty, A.; Mauersberger, S.; Smit, M.S.; Nicaud, J.-M. Hydrophobic substrate utilisation by the yeast Yarrowia lipolytica, and its potential applications. FEMS Yeast Res. 2005, 5, 527-543. 
4. Fantin, G.; Fogagnolo, M.; Medici, A.; Pedrini, P.; Fontana, S. Kinetic resolution of racemic secondary alcohols via oxidation with Yarrowia lipolytica strains. Tetrahedron-Asymmetry 2000 , 11, 2367-2373.

5. Kroutil, W.; Mang, H.; Edegger, K.; Faber, K. Biocatalytic oxidation of primary and secondary alcohols. Adv. Synth. Catal. 2004, 346, 125-142.

6. Leskovac, V.; Trivic, S.; Pericin, D. The three zinc-containing alcohol dehydrogenases from baker's yeast. FEMS Yeast Res. 2002, 2, 481-494.

7. Dujon, B.; Sherman, D.; Fischer, G.; Durrens, P.; Casaregola, S.; Lafontaine, I.; de Montigny, J.; Marck, C.; Neuveglise, C.; Talla, E.; et al. Genome evolution in yeasts. Nature 2004, 430, 35-44.

8. Reid, M.F.; Fewson, C.A. Molecular characterization of microbial alcohol dehydrogenases. Crit. Rev. Microbiol. 1994, 20, 13-56.

9. Passoth, V.; Schäfer, B.; Liebel, B.; Weierstall, T.; Klinner, U. Yeast sequencing reports-molecular cloning of alcohol dehydrogenase genes of the yeast Pichia stipitis and identification of the fermentative ADH. Yeast 1998, 14, 1311-1325.

10. Lin, Y.; He, P.; Wang, Q.; Lu, D.; Li, Z.; Wu, C.; Jiang, N. The alcohol dehydrogenase system in the xylose-fermenting yeast Candida maltosa. PLoS One 2010, 5, e11752.

11. Suwannarangsee, S.; Oh, D.-B.; Seo, J.-W.; Kim, C.H.; Rhee, S.K.; Kang, H.A.; Chulalaksananukul, W.; Kwon, O. Characterization of alcohol dehydrogenase 1 of the thermotolerant methylotrophic yeast Hansenula polymorpha. Appl. Microbiol. Biotechnol. 2010, 88, 497-507.

12. Yurimoto, H.; Lee, B.; Yasuda, F.; Sakai, Y.; Kato, N. Alcohol dehydrogenases that catalyse methyl formate synthesis participate in formaldehyde detoxification in the methylotrophic yeast Candida boidinii. Yeast 2004, 21, 341-350.

13. PSORT II Prediction. Available online: http://psort.hgc.jp/form2.html (accessed on 12 September 2012).

14. Napora, K.; Wrodnigg, T.M.; Kosmus, P.; Thonhofer, M.; Robins, K.; Winkler, M. Yarrowia lipolytica dehydrogenase/reductase: An enzyme tolerant for lipophilic compounds and carbohydrate substrates. Bioorg. Med. Chem. Lett. 2013, 23, 3393-3395.

15. Huanting, L.; Naismith, J.H. A simple and efficient expression and purification system using two newly constructed vectors. Protein Expr. Purif. 2009, 63, 102-111.

16. Balzer, D.; Ziegelin, G.; Pansegrau, W.; Kruft, V.; Lanka, E. Kor B protein of promiscuous plasmid RP4 recognizes inverted sequence repetitions in regions essential for conjugative plasmid transfer. Nucleic Acid Res. 1992, 20, 1851-1858.

17. Saerens, K.; van Bogaert, I.; Soetaert, W.; Vandamme, E. Production of glucolipids and specialty fatty acids from sophorolipids by Penicillium decumbens naringinase: Optimization and kinetics. Biotechnol. J. 2009, 4, 517-524.

18. Kosjek, B.; Stampfer, W.; Pogorevc, M.; Goessler, W.; Faber, K.; Kroutil, W. Purification and characterization of a chemotolerant alcohol dehydrogenase applicable to coupled redox reactions. Biotechnol. Bioeng. 2004, 86, 55-62. 
19. Pennacchio, A.; Sannino, V.; Sorrentino, G.; Rossi, M.; Raia, C.A.; Esposito, L. Biochemical and structural characterization of recombinant short-chain $\mathrm{NAD}(\mathrm{H})$-dependent dehydrogenase/reductase from Sulfolobus acidocaldarius highly enantioselective on diaryl diketone benzyl. Appl. Microbiol. Biotechnol. 2013, 97, 3949-3964.

20. DeWildeman, S.; Sereinig, N. Enzymatic Reduction of Carbonyl Groups. In Science of Synthesis, Stereoselective Synthesis; De Vries, J.G., Molander, G.A., Evans, P.A., Eds.; Georg ThiemeVerlag: Stuttgart, Germany, 2011; pp. 113-208;

21. Hollmann, F.; Arends, I.W.C.E.; Buehler, K.; Schallmey, A.; Buehler, B. Enzyme-mediated oxidations for the chemist. Green Chem. 2011, 13, 226-265.

22. Mädje, K.; Schmölzer, K.; Nidetzky, B.; Kratzer, R. Host cell and expression engineering for development of an E. coli ketoreductase catalyst: Enhancement of formate dehydrogenase activity for regeneration of NADH. Microb. Cell Fact. 2012, 11, 1-7.

23. Anelli, P.L.; Tomba, C.; Uggeri, F. Optical resolution of 2-chloro-3-phenylmethoxypropanoic acid after derivatization with $(S)$-2-octanol by high-performance liquid chromatography. J. Chromatogr. 1992, 589, 346-348.

24. Threeprom, J. (S)-(+)-2-Octanol as a chiral oil core for the microemulsion electrokinetic chromatographic separation of chiral basic drugs. Anal. Sci. 2007, 23, 1071-1075.

25. Parra, M.; Vergara, J.; Hildalgo, P.; Barbera, J.; Sierra, T. (S)-Isoleucine and $(R)$-2-octanol as chiral precursors of new chiral liquid crystalline thiadiazoles: Synthesis, mesomorphic and ferroelectric properties. Liquid Cryst. 2006, 33, 739-745.

26. Hoffman, C.S.; Winston, F. A ten-minute DNA preparation from yeast efficiently releases autonomous plasmids for transformation of Escherichia coli. Gene 1987, 57, 267-272.

27. Brouns, S.J.; Turnbull, A.P.; Willemen, H.L.; Akerboom, J.; van der Oost, J. Crystal structure and biochemical properties of the D-arabinose dehydrogenase from Sulfolobus solfataricus. J. Mol. Biol. 2007, 371, 1249-1260.

28. Silva, C.R.; Souza, J.C.; Araújo, L.S.; Kagohara, E.; Garcia, T.P.; Pelizzari, V.H.; Andrade, L.H. Exploiting the enzymatic machinery of Arthrobacter atrocyaneus for oxidative kinetic resolution of secondary alcohols. J. Mol. Catal. B: Enzym. 2012, 83, 23-28.

(C) 2013 by the authors; licensee MDPI, Basel, Switzerland. This article is an open access article distributed under the terms and conditions of the Creative Commons Attribution license (http://creativecommons.org/licenses/by/3.0/). 